\title{
ABCG2 wt Allele
}

National Cancer Institute

\section{Source}

National Cancer Institute. ABCG2 wt Allele. NCI Thesaurus. Code C52276.

Human ABCG2 wild-type allele is located within $4 \mathrm{q} 22$ and is approximately $67 \mathrm{~kb}$ in length.

This allele, which encodes ATP-binding cassette sub-family G member 2 protein, plays a

role in transmembrane transport and transcriptional regulation. The allele is thought to

play a role in cellular defense and aberrations are thought to play a role in tumor

multidrug resistance. 